\title{
Fat mobilization in Pietrain and Large White pigs
}

\author{
By J. D. WOOD, N. G. GREGORY, G. M. HALL AND D. LISTER \\ $A R C$ Meat Research Institute, Langford, Bristol $B S_{\mathrm{I}} 87^{D Y}$
}

(Received 4 December 1975 - Accepted 20 August 1976)

\begin{abstract}
1. Two experiments were done with Pietrain and Large White pigs (about $50 \mathrm{~kg}$ bodyweight) to determine whether fat mobilization is enhanced in the stress-sensitive Pietrains (which also produce pale, soft, exudative (PSE) meat).

2. In Expt 1 , plasma glucose and insulin concentrations and free fatty acid (FFA) concentrations and composition were measured in five Pietrains and five Large Whites after feeding, during an infusion of norepinephrine $(2.5 \mu \mathrm{g} / \mathrm{kg}$ body-weight per $\min ), 16$ and $21 \mathrm{~h}$ after the withdrawal of food and following insulin administration $(0.3 \mathrm{IU} / \mathrm{kg}$ body-weight). The entry rate of oleic acid was measured $4 \mathrm{~h}$ after feeding. Body composition and longissimus dorsi $\mathrm{pH}$ measurements were made on killing the pigs $4 \mathrm{~d}$ after the experiment.
\end{abstract}

3. After feeding, the Pietrains tended to have lower concentrations of glucose and insulin in plasma compared with the Large Whites, and higher concentrations of FFA. The Pietrains also had a faster entry rate of oleic acid into body tissues. In fasting ( $16 \mathrm{~h}$ ) these differences in hormone and metabolite concentrations were also present and relationships between them and body development could be detected. Pietrains had higher concentrations of FFA and lower concentrations of insulin than Large Whites at a particular stage of the development of fat and muscle (subcutaneous fat weight $\div$ longissimus muscle weight).

4. The fatty acid composition of FFA resembled that of the backfat triglycerides in fasting and during norepinephrine infusion but not in the fed state. In particular the proportion of fatty acid $\mathrm{I} 8: \mathrm{I}$ was low in the fed pigs and that of $\mathrm{I} 8: 2$ was high. The contrast in FFA composition between the fed and stimulated state was greater in the Large Whites.

5. The Pietrains were less sensitive to the antilipolytic action of insulin. Glucose and FFA concentrations were similar in both breeds during the norepinephrine infusion although insulin concentrations were increased to a larger extent in the Large Whites at the termination of the infusion.

6. In Expt 2, anaesthetized Pietrain and Large White pigs were given constant infusions of norepinephrine alone $(2.5 \mu \mathrm{g} / \mathrm{kg}$ body-weight per $\mathrm{min}$ ) and norepinephrine + propranolol ( 2 , ro and $20 \mu \mathrm{g} / \mathrm{kg}$ body-weight per $\mathrm{min}$ ) or phentolamine ( 2 and $10 \mu \mathrm{g} / \mathrm{kg}$ body-weight per $\mathrm{min}$ ). The aim was to determine whether the breeds differed in their sensitivity to norepinephrine when conscious responses to the hormone were prevented.

7. When norepinephrine alone was infused, fat mobilization was greater in the Pietrain pigs and glucose concentrations were greater in the Large Whites. Propranolol markedly reduced the lipolytic action of norepinephrine, particularly in the Pietrain pigs studied, and phentolamine reduced its glycogenolytic action, particularly in the Large White pig.

8. It seems that the leanness of stress-sensitive, PSE-susceptible Pietrain pigs may be due to an enhanced fat mobilization under various conditions, associated with an impairment in insulin metabolism and a greater sensitivity to the $\beta$-adrenergic action of catecholamines on body fat stores.

Two potentially serious problems in pigmeat production are stress-sensitivity in the growing animals and pale, soft, exudative (PSE) meat in their carcasses after death. The problems often occur together, most commonly in the leanest pigs, and because of this it has been suggested that there is a physiological association between carcass leanness and PSE- and stress-sensitivity (Ludvigsen, I955; Bendall \& Lawrie, I964). The nature of the association has not been established.

Most work on this subject has concentrated on the possibility of an association between the incidence of PSE meat and various aspects of skeletal muscle metabolism. 
However, it is clear that genotypic differences in body composition are primarily caused by differences in fat deposition. The breeds or strains which produce PSE meat also have noticeably less body fat than those which do not (e.g. Bray, 1968). Other evidence (for instance the genetic correlations presented by Jensen, Craig \& Robison, 1967) suggests that there might be a fundamental relationship between the capacity to deposit body fat and the PSE-stress-sensitivity syndrome.

Improvement in carcass leanness in pigs can be achieved indirectly by selecting breeding animals on the basis of low-backfat thickness. When this was done in Norwegian Landrace pigs, the low-backfat animals apparently developed a greater ability to mobilize body fat than medium- or high-backfat animals (Standal, Vold, Trygstad \& Foss, 1973). Adipose tissue slices from the low-backfat animals were more sensitive to lipolytic hormones in vitro and serum from the low-backfat pigs had a smaller antilipolytic action when injected into rabbits. In addition the fasting serum free fatty acid (FFA) levels have been found to be higher in pigs from the low-backfatthickness strain than in the high-backfat animals (Bakke, I975). The possibility that such a pattern of fat metabolism might also develop in lean PSE pigs was suggested by the work of Marple, Aberle, Forrest, Blake \& Judge (1972), who showed that Poland China pigs of a stress-sensitive type had slightly higher resting plasma FFA concentrations and a greater lipolytic response to heat or cold stress than stressresistant Chester Whites of the same body-weight. Differences in hormone metabolism were thought to be responsible. In humans, stressful or emotional states are also associated with high concentrations of plasma FFA (Bogdonoff \& Estes, 196r; Taggart, Carruthers \& Somerville, 1973).

The present studies were therefore undertaken to determine whether fat mobilization is enhanced in Pietrain compared with Large White pigs in vivo. If this was the situation it would provide a possible physiological explanation for the association between PSE meat, stress-sensitivity and carcass leanness.

EXPERIMENTAL

In Expt I a study was made of carbohydrate and FFA metabolism in Pietrain and Large White pigs after feeding, during an infusion of norepinephrine, during fasting, and after insulin administration. In Expt 2 the effects of infused norepinephrine were studied in anaesthetized pigs.

\section{Expt I}

Five Pietrain and five Large White pigs (mean live weight $(\mathrm{kg}) \pm \mathrm{SE}, 5 \mathrm{I} \pm 2$ ) from minimal-disease herds were used. There were three castrated males and two females of each breed. One week before the experiment each pig was fitted with indwelling cannulas (Portex PP 160) in both external jugular veins, the cannulas being brought out behind the ears and taped to the pig's neck. This operation was carried out under sodium pentobarbitone, nitrous oxide and oxygen anaesthesia. The pigs were then housed in conventional metabolism crates and fed to appetite twice daily for $\mathrm{I} h$ a commercial pig feed (BOCM Super Hialean nuts containing $160 \mathrm{~g}$ crude protein (nitrogen $\times 6 \cdot 25) / \mathrm{kg}$ which they had been fed ad lib. from weaning). The cannulas 
were flushed with heparin in saline (9 $\mathrm{g}$ sodium chloride/l) $(0 \cdot 2 \mathrm{I} . \mathrm{U} . / 2 \mathrm{ml})$ twice daily. An experiment with each pig took $2 \mathrm{~d}$. On day I the pig ate from 08.30 to 09.30 hours. From 09.30 until 16.00 hours constant infusions $(0.4 \mathrm{ml} / \mathrm{min})$ were given using a syringe injection pump. The infusions were: from 09.30 until 13.30 hours, $\left[{ }^{3} \mathrm{H}\right]-$ oleic acid $(2 \cdot 0 \mu \mathrm{Ci} / \mathrm{min})$; from 13.30 until 14.30 hours, norepinephrine $(2.5 \mu \mathrm{g} / \mathrm{kg}$ body-weight per min); from 14.30 until $\mathrm{I} 6.00$ hours, saline. Blood samples (Io $\mathrm{ml}$ ) were taken from the opposite cannula at 20 min intervals. At 16.00 hours the animals were given $200 \mathrm{~g}$ pig nuts, an amount which they ate readily.

On day 2 the pigs were not given a morning feed. Blood samples were taken at 09.00 and $\mathrm{I} 4.00$ hours ( $\mathrm{I} 6$ and $2 \mathrm{I} \mathrm{h}$ respectively after the $200 \mathrm{~g}$ meal) and at $\mathrm{I} 4.00$ hours a single intravenous injection of insulin (0.3 IU/kg body-weight) was given. Blood samples were collected at intervals up to 180 min postinjection, when the animals were allowed free access to food.

After a further $4 \mathrm{~d}$ in their metabolism crates, with twice-daily feeding, the pigs were killed by electrical stunning and exsanguination. Samples $(3 \circ \mathrm{g})$ of the longissimus dorsi muscle from the lumbar region of the left side of the carcass were immediately taken for $\mathrm{pH}$ measurements at $0,45 \mathrm{~min}$ and $24 \mathrm{~h}$ post mortem (Lister \& Ratcliff, 197 I). The intact longissimus muscle and the total subcutaneous fat (minus skin) from the right side of the carcass were then dissected out and weighed.

Some preliminary results from this experiment have been reported previously (Wood, 1974).

\section{Expt 2}

Seven non-fasted Large White and six non-fasted Pietrain pigs (mean live weight $(\mathrm{kg}) \pm \mathrm{SE}, 54 \pm 2$ ) were anaesthetized in their pens with sodium pentobarbitone, via an ear vein. They were then maintained under anaesthesia for the duration of the experiment with sodium pentobarbitone and ventilated with $\mathrm{N}_{2} \mathrm{O}$ and $\mathrm{O}_{2}$. Two cannulas (Portex PP I60) were inserted into both external jugular veins, one to be used for infusions $(0.2 \mathrm{ml} / \mathrm{min}$ ) and the other for collection of blood samples (10 $\mathrm{ml}$ ).

In the first part of Expt 2 four Large Whites and three Pietrains were used to study the effect of infused norepinephrine on plasma FFA, glucose and insulin concentrations. The study proceeded as follows: an infusion of saline was begun after insertion of the two cannulas and blood samples were taken at 30 and $40 \mathrm{~min}$. From 50 to $100 \mathrm{~min}$ an infusion of norepinephrine $(2.5 \mu \mathrm{g} / \mathrm{kg}$ body-weight per min) was given. Finally from 100 to $160 \mathrm{~min}$ a second infusion of saline was given. Blood samples were taken throughout for analysis.

In the second part of Expt 2, constant infusions of propranolol or phentolamine were imposed on the norepinephrine infusion. There were three pairs of pigs, each pair consisting of one pig from each breed. The first pair was used to study the effect of two levels of $\beta$-adrenergic blockade ( 2 and $20 \mu \mathrm{g}$ propranolol $/ \mathrm{kg}$ body-weight per min) on norepinephrine-stimulated glycogenolysis, lipolysis and insulin metabolism; the second pair was used to study the effect of an intermediate level of $\beta$-blockade (ro $\mu \mathrm{g}$ propranolol $/ \mathrm{kg}$ body-weight per min); and the third pair was used to study the effect of two levels of $\alpha$-blockade ( 2 and $10 \mu \mathrm{g}$ phentolamine $/ \mathrm{kg}$ body-weight per min). The experimental procedure for each pair was similar and is given in the Results section. 


\section{Analytical methods}

Freshly collected blood was chilled in crushed ice and immediately centrifuged at I $500 \mathrm{~g}$ for ${ }_{15} \mathrm{~min}$ to obtain plasma. FFA concentrations were then determined in I $\mathrm{ml}$ plasma by extraction with Dole's solution (Dole \& Meinertz, 1960) followed by estimation using Duncombe's ( 1963$)$ procedure as modified by Ho (1970) to remove phospholipids.

The fatty acid composition and the radioactivity of plasma FFA were also determined in plasma samples extracted using Dole's solution: $2 \mathrm{ml}$ plasma were used for radioactivity measurements and 2-10 $\mathrm{ml}$ (depending on the concentration of plasma FFA) for measuring FFA composition. Phospholipids were removed in $5 \mathrm{mM}-$ sulphuric acid (Trout, Estes \& Friedberg, 1960) and FFA were extracted into alkaline ethylene glycol (Kaplan, 1970) containing thymol blue indicator (Borgstrom, 1952). The FFA were precipitated using $0.05 \mathrm{M}^{-} \mathrm{H}_{2} \mathrm{SO}_{4}$ and taken up into light petroleum (b.p. 40-60 ) either for liquid-scintillation counting of radioactivity (Packard Tricarb Model 3375; Packard Instrument Co., Downers Grove, Illinois, USA), after evaporation of the light petroleum, or for measurement of composition by gas-liquid chromatography. The methyl esters of the FFA were prepared using diazomethane and the chromatograph (Pye-Unicam Model ro4; Pye-Unicam Ltd, Cambridge) was operated as described previously (Wood \& Lister, I973). Glucose concentrations were measured using the glucose-oxidase kit supplied by Boehringer $\mathrm{GmbH}$ (Mannheim, West Germany).

Insulin concentrations were measured by solid-phase radioimmunoassay (Phadebas insulin test; Pharmacia Ltd, Uppsala, Sweden). The samples were counted using an automatic gamma analyser (Philips model PW 4520; Pye-Unicam Ltd) and the results were calculated with the aid of a computer (model 342 computer; Compucorp, Los Angeles, California, USA) using a maximum likelihood curve-fitting programme developed at Rothamsted Experimental Station. The mean power point rating for the assays, calculated according to the method of Cerceo (1974), was 21 .

\section{Preparation of infusion solutions and calculation of FFA entry rate}

Norepinephrine bitartrate (lot 920-2190; Sigma Chemical Co., St Louis, Missouri, USA) was freshly made up in saline to which ascorbic acid ( $\mathrm{g} / \mathrm{l})$ was added as an antioxidant. Insulin was administered as a sterile solution in water (lot 2225; Allan and Hanburys Ltd, Ware, Herts.).

$\left[9,10-{ }^{3} \mathrm{H}\right]$ oleic acid $(2.5 \mathrm{Ci} / \mathrm{mmol}$, Code TRK 140 , batch $\mathrm{II})$ was obtained from The Radiochemical Centre (Amersham, Bucks) and infused as its sodium salt in albumin (Laurell, 1957) contained in saline. It was found in preliminary studies that the specific radioactivity (SR) of plasma oleic acid (counts/min per $\mu \mathrm{mol}$ ) was constant during the $3^{\text {rd }}-4^{\text {th }}$ hour of the infusion on day $\mathrm{I}$, when the plasma FFA concentration was also constant. Under these conditions the entry rate of oleic acid into the tissues of the pigs $(\mu \mathrm{mol} / \mathrm{min}$ per $\mathrm{kg}$ live weight) was obtained by dividing the rate of infusion of radioactivity (counts/min) by the SR (Leat \& Ford, 1966). Propranolol 
Table I. Expt I. Influence of feeding and fasting ( 16 h after $200 \mathrm{~g}$ meal) on plasma glucose, free fatty acid (FFA) and insulin concentrations in five Pietrain and five Large White pigs

(Mean values with their standard errors; values for individual pigs are the means of two (insulin) or four (FFA and glucose) determinations)

\begin{tabular}{|c|c|c|c|c|c|c|c|}
\hline & \multicolumn{4}{|c|}{ Influence of feeding $\dagger$} & \multirow{2}{*}{\multicolumn{3}{|c|}{ Influence of fasting }} \\
\hline & \multirow[b]{2}{*}{$\begin{array}{r}\text { Glucose } \\
(\mathrm{mmol} / \mathrm{l})\end{array}$} & \multirow[b]{2}{*}{$\begin{array}{c}\text { FFA } \\
(\mu \mathrm{mol} / \mathrm{l})\end{array}$} & \multirow{2}{*}{$\begin{array}{c}\text { Entry rate } \\
\text { of oleic acidt } \\
\text { ( } \mu \mathrm{mol} / \mathrm{min} \\
\text { per } \mathrm{kg} \\
\text { body-weight) }\end{array}$} & \multirow[b]{2}{*}{$\begin{array}{l}\text { Insulin } \\
(\mu \mathrm{U} / \mathrm{ml})\end{array}$} & & & \\
\hline & & & & & $\begin{array}{l}\text { Glucose } \\
(\mathrm{mmol} / \mathrm{l})\end{array}$ & $\begin{array}{c}\mathrm{FFA} \\
(\mu \mathrm{mol} / \mathrm{l})\end{array}$ & $\underset{(\mu \mathrm{U} / \mathrm{ml})}{\text { Insulin }}$ \\
\hline Pietrain & $\begin{array}{l}6.6 \pm 0.4 \\
7.2+0.4\end{array}$ & I $78 \pm 39^{*}$ & $\begin{array}{l}2.04 \pm 0.37 * \\
1.05+0.08\end{array}$ & $\begin{array}{l}33.7 \pm 8.8 * \\
54.8+7.7\end{array}$ & $\begin{array}{l}5.9 \pm 0.2 \\
5.7+0.3\end{array}$ & $\begin{array}{l}617 \pm 118 * * \\
337 \pm 66\end{array}$ & $\begin{array}{l}16.3 \pm 0.6 * \\
20.4 \pm 1 \cdot 1\end{array}$ \\
\hline
\end{tabular}

(Inderal; ICI Pharmaceuticals Ltd, Macclesfield, Cheshire) and phentolamine (Rogitine; CIBA Ltd, Horsham, Sussex) were made up in saline.

\section{RESULTS}

\section{Expt I}

The influence of feeding, fasting, insulin administration and infused norepinephrine on plasma glucose, FFA and insulin concentrations

The results are shown in Tables I, 2 and 3 . After feeding the Pietrains tended to have higher concentrations of FFA in plasma and lower concentrations of glucose and insulin than the Large Whites but the breed differences were not significant $(P<0.05)$. In Pietrains the higher concentrations of FFA, and therefore of oleic acid (the concentration of oleic acid in FFA (mg/g) \pm SE was: $363 \pm 14$ and $301 \pm 27$ for Pietrains and Large Whites respectively), also resulted in a faster entry rate of oleic acid into the tissues of these pigs. There was no evidence of a different relationship between the concentration $(X ; \mu \mathrm{mol} / 1)$ and entry rate $(Y ; \mu \mathrm{mol} / \mathrm{min}$ per $\mathrm{kg}$ body-weight $)$ of oleic acid in the two breeds and all the results could be described by a linear regression equation: $Y=0.49+(0.023 \pm 0.005) X(r 0.84, P<0.05)$. The calculated oleic acid entry rates are similar to those that Freeman, Noakes \& Annison (1970) found in two 6-12 week-old Large White $\times$ Wessex pigs $(\mathrm{I} \cdot 8$ and $\mathrm{I} \cdot 0 \mu \mathrm{mol} / \mathrm{min}$ per $\mathrm{kg}$ body-weight respectively). Assuming that plasma constituted $5 \%$ of body-weight (Riis \& Grummer, r 969 ), then the estimated turnover time (min) $\pm \mathrm{SE}$ of plasma oleic acid in the present study was $1 \cdot 30 \pm 0 \cdot 13 \mathrm{~min}$ for all ten pigs.

The concentrations of glucose and insulin were lower and the concentrations of FFA were higher in both breeds after the overnight fast than during feeding the previous day. Our preliminary work had shown that plasma FFA concentrations begin to increase to values higher than those in the fed state about $16 \mathrm{~h}$ after the removal of 


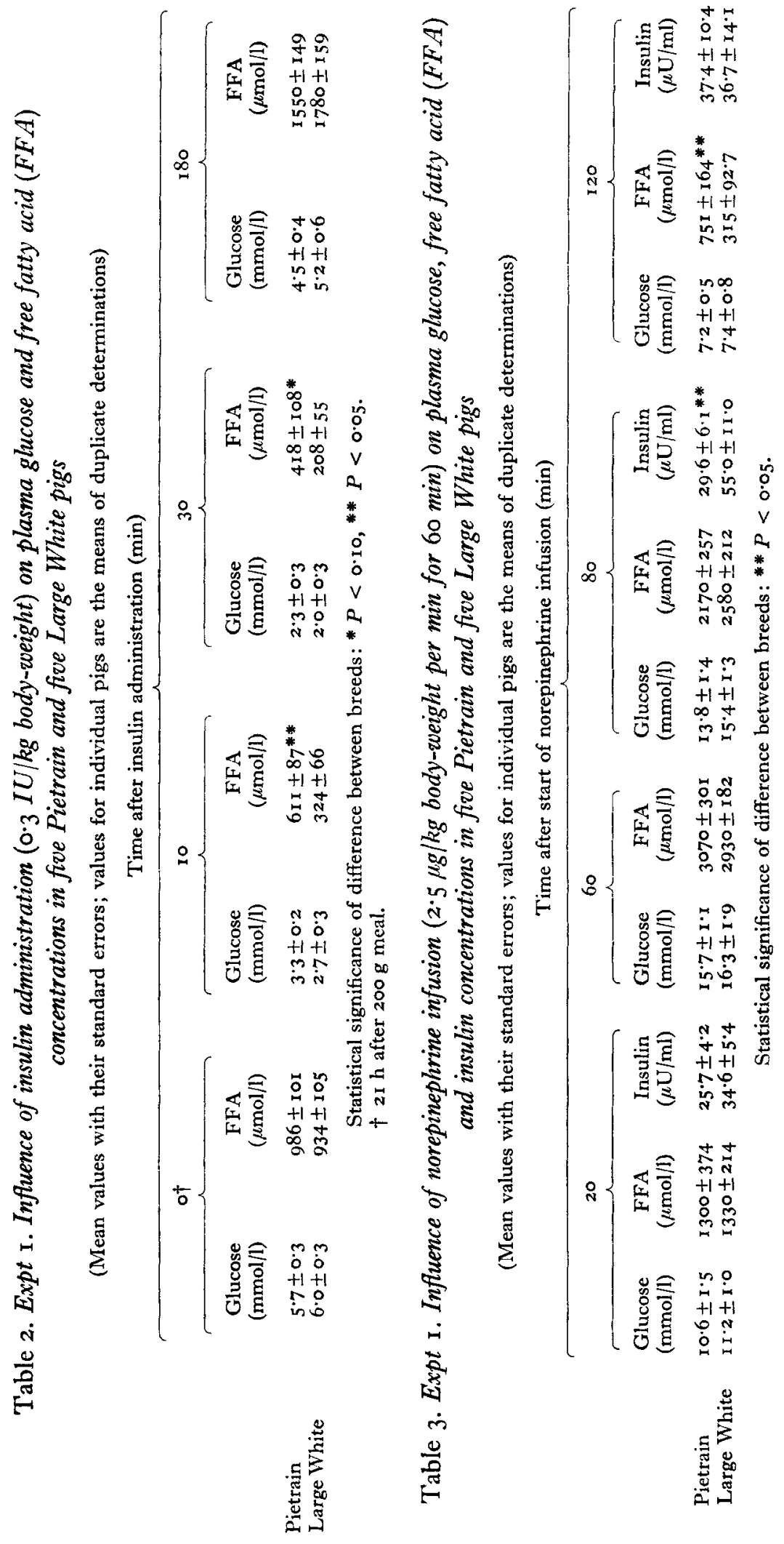


food. This probably explains why Freeman $e t$ al. (1970) found a variable and nonsignificant increase in FFA concentrations in their pigs at exactly $16 \mathrm{~h}$. In the present study the $200 \mathrm{~g}$ meal was intended to offset a severe energy loss due to the catecholamine infusion; it was not sufficiently large to serve as a major meal. Therefore FFA concentrations were high $\mathrm{I} 6 \mathrm{~h}$ after the pigs had eaten it. At this time the concentrations of FFA were higher and those of insulin were lower in the Pietrain compared with the Large White pigs. These results, together with those obtained on day I, suggest that the circulating levels of FFA are consistently higher and those of insulin are lower throughout the day in these pigs.

Exogenous insulin significantly reduced plasma glucose and FFA levels in both breeds, and the Large Whites were found to be more sensitive to the antilipolytic action of insulin. There was a marked increase in FFA concentrations from 30 to $180 \mathrm{~min}$ after insulin administration, which was greater in the Large Whites. This may have been due to the slightly greater hypoglycaemia in these pigs (Freeman et al. 1970).

Norepinephrine caused the pigs to become restless and excited and elicited a marked increase in the plasma glucose and FFA levels. In the ten pigs, norepinephrine reduced the plasma insulin level within 20 min of the commencement of the infusion $(P<0.05)$. The values (mean $\pm \mathrm{SE}$ ) were: 0 min $52.5 \pm 10.8,20 \mathrm{~min} 30.2 \pm 3.5$. However, this effect was not significant when considering values within either of the breeds. The values of $3 \mathrm{mmol} \mathrm{FFA} / 1$ plasma and $16.0 \mathrm{mmol}$ glucose $/ 1$ plasma obtained at the termination of the infusion are similar to those recorded by Hertelendy, Machlin, Gordon, Horino \& Kipnis (1966) at the end of a 60 min infusion of epinephrine ( $\mathrm{r} \mu \mathrm{g} / \mathrm{kg}$ live weight per min) in three pigs of unspecified breed (20-50 kg live weight). The values are also similar to those recorded by Cunningham \& Friend (1965) $2 \mathrm{~h}$ after subcutaneous administration of norepinephrine to $25 \mathrm{~kg}$ Yorkshire pigs. In the latter study the amount of norepinephrine administered was $0.08 \mathrm{mg} / \mathrm{kg}$ live weight (in the present work the total amount given over $60 \mathrm{~min}$ was $0.15 \mathrm{mg} / \mathrm{kg}$ live weight). Studies done in vitro have also shown that pig adipose tissue is extremely sensitive to the lipolytic action of the catecholamines, particularly norepinephrine (Mersmann, Brown, Underwood \& Stanton, 1974).

There was an indication that recovery of insulin levels to pre-infusion values occurred $20 \mathrm{~min}$ after termination of the norepinephrine infusion. This was more apparent in the Large Whites than in the Pietrains.

\section{Fatty acid composition of plasma FFA}

The contribution of the six major fatty acids to plasma FFA in the pigs $3-4 \mathrm{~h}$ after feeding, at the termination of the norepinephrine infusion, and $2 \mathrm{r} \mathrm{h}$ after the $200 \mathrm{~g}$ meal, is shown in Fig. I. The values given represent the ratio, proportion $(\mathrm{mg} / \mathrm{g})$ of fatty acid in the FFA: proportion of fatty acid $(\mathrm{mg} / \mathrm{g})$ in backfat triglyceride fatty acids (lower layer of mid-shoulder fat). Values greater than $\mathrm{I} \cdot \mathrm{O}$ reflect preferential mobilization and values less than $\mathrm{I} \cdot \circ$ reflect preferential retention of the fatty acid in backfat, although this can only be an approximation since the composition of depot fat varies between sites and there is no way of knowing the extent to which mobilization occurs from each site. There was a change in the composition of FFA as FFA 


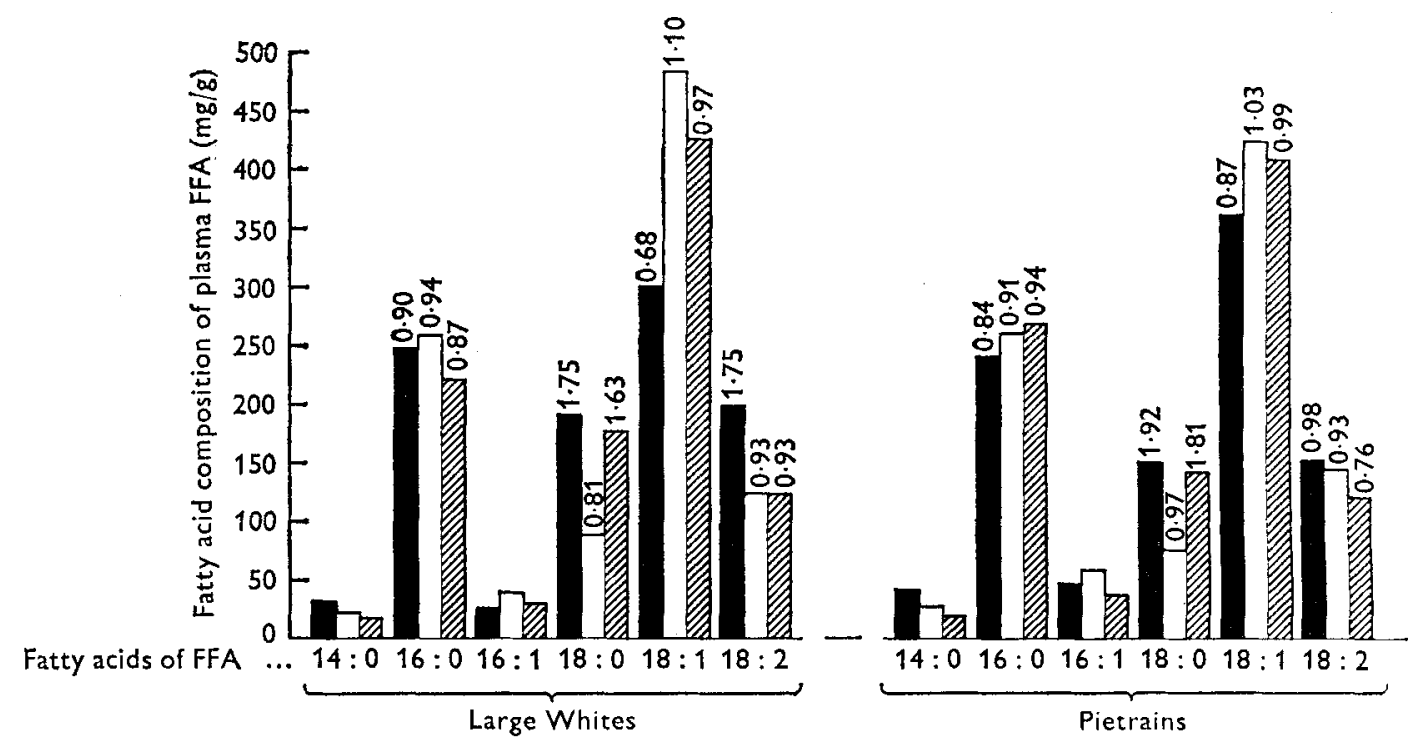

Fig. 1. Expt 1. Fatty acid composition of plasma free fatty acids (FFA) in five Pietrain and five Large White pigs after feeding ( body-wt per min) (day I) ( $\square$ ) and after $2 \mathrm{I} \mathrm{h}$ fast (day 2 ) (W). The values given for each fatty acid represent the ratio, proportion of each fatty acid in FFA $(\mathrm{mg} / \mathrm{g})$ : proportion of fatty acid in backfat triglyceride fatty acids (lower layer mid-shoulder fat) (mg/g). For details of experimental procedures, see p. 168 .

concentrations increased under the influence of norepinephrine and fasting. In particular the proportion of fatty acid $18: 1$ (oleic acid) increased and that of $18: 2$ (linoleic acid) decreased. These changes in composition were more marked in the Large Whites, probably because they were mobilizing less fat than the Pietrains after feeding, and consequently had lower proportions of $18: 1$ and higher proportions of $18: 2$ in FFA at that time. In the Large Whites the following proportions of $18: 1$ and $18: 2$ $(\mathrm{mg} / \mathrm{g}) \pm \mathrm{SE}$ were found (after feeding, after norepinephrine infusion and after fasting respectively): I $8: 1: 301 \pm 27,485 \pm 15,428 \pm 7$; I8:2:200 $\pm 20,105 \pm 8$, 106 \pm 6 ; the corresponding values in Pietrains were $(\mathrm{mg} / \mathrm{g}): 18: \mathrm{I}: 363 \pm \mathrm{I} 4,429 \pm 29,4 \mathrm{II} \pm \mathrm{I} 7$; $18: 2: 154 \pm 24,146 \pm 8,119 \pm 17$. In contrast to these results, the corresponding values for the proportion of $16: 0$ (palmitic acid) in FFA were similar for both breeds.

In general the changes in FFA composition under the influence of fasting and norepinephrine resulted from a mobilization that was representative of the fatty acids in backfat (whereas mobilization in fed pigs tended to be unrepresentative, particularly in the Large Whites). The composition of FFA in both stimulated states was similar except for 18:0 (stearate) which was apparently mobilized much more readily in fasting than under the influence of norepinephrine. In the Large Whites the following proportions of $18: 0(\mathrm{mg} / \mathrm{g}) \pm \mathrm{SE}$ were obtained (after feeding, after norepinephrine infusion and after fasting respectively): $191 \pm 14,88 \pm 4,178 \pm 11$. In the Pietrains the corresponding values were $(\mathrm{mg} / \mathrm{g}) \pm \mathrm{SE}: 152 \pm 7,76 \pm 10,143 \pm 12$. The apparent preferential mobilization of $18: 2$ in fed Large Whites was associated with a smaller proportion of this fatty acid in the triglycerides of the lower layer of shoulder fat; the values 
were $(\mathrm{mg} / \mathrm{g}) \pm \mathrm{SE}: 114 \pm 14$ and $157 \pm 13$ in Large Whites and Pietrains respectively $(P<0.05)$. A similar difference in backfat (Wood, 1973) and muscle neutral lipid (Wood \& Lister, 1973) has been reported previously.

The relationships between the postfeeding plasma insulin level (mean of two samples

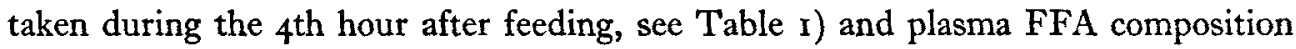
were determined in each breed. The plasma insulin level was negatively correlated with the proportion of $\mathrm{I} 8: \mathrm{I}$ in the FFA in both Large Whites $(r-0.89, P<0.05)$ and Pietrains $(r-0.70, P<0.05)$. The plasma insulin level was positively correlated with the proportion of 16:0+18:0 in Large Whites $(r 0.94, P<0.05)$ and negatively correlated with the proportion of $16: 0+18: 0$ in Pietrains $(r-0.95, P<0.05)$. These significant correlations suggest that insulin is important in regulating FFA composition. The positive and negative nature of the various correlation coefficients in the relationship between insulin and $16: 0+18: 0$ in the two breeds is interesting in the light of observations made by Bonnet, Gosselin, Chantraine \& Senterre (1970) in obese and non-obese children. Administration of an intravenous glucose load caused a transitory increase in the proportion of $16: 0+18: 0$ in the non-obese subjects but a much more marked increase in the obese subjects. Therefore the difference found in our study between Pietrains and Large Whites might have reflected a metabolic difference associated with their divergent body compositions (Table 4 ).

\section{Body composition and meat quality}

The results are given in Table 4 . The significantly higher value for subcutaneous fat: longissimus muscle weight in the Large Whites suggests that these pigs were fatter despite their slightly smaller live weights. However, the breed difference was not as large as has been reported elsewhere (Lean, Curran, Duckworth \& Holmes, 1972; Wood \& Lister, 1973). It has been suggested that the leanness of Pietrains is due partly to their small appetites which result in sufficient energy for muscle growth but insufficient for excessive fat growth (Perry \& Wood, unpublished results). On the day before the present experiment began the weights of food consumed $(\mathrm{g}) \pm \mathrm{SE}$ were: $1928 \pm 139$ and $1325 \pm 69$ for Large Whites and Pietrains respectively $(P<0.05)$. Both amounts are less than would have been consumed by animals fed $a d l i b$. and allowed exercise and are probably the result of confining the pigs in metabolism crates. However, the breed difference in food consumed $(30 \%)$ is similar to that seen in studies comparing Pietrains with Landrace (Lean et al. 1972) or Large White pigs (Perry \& Wood, unpublished results). In their single meal before the experiment commenced on day I the pigs of both breeds ate similar amounts of food $(723 \pm 30 \mathrm{~g})$.

The longissimus dorsi $\mathrm{pH}$ values were significantly lower in Pietrains at $45 \mathrm{~min}$ post mortem ('Table 4 ). The rapid decrease in $\mathrm{pH}$ has been shown to lead to PSE muscle in Pietrains by causing denaturation of the muscle proteins and a loss of their water-binding capacity (Lister \& Ratcliff, 197I).

To determine whether the breed differences in tissue development were causally related to the physiological measurements made, statistical relationships were studied. These were not significant when the measurements made after feeding were the dependent variables, possibly because of the low rate of fat mobilization occurring at 


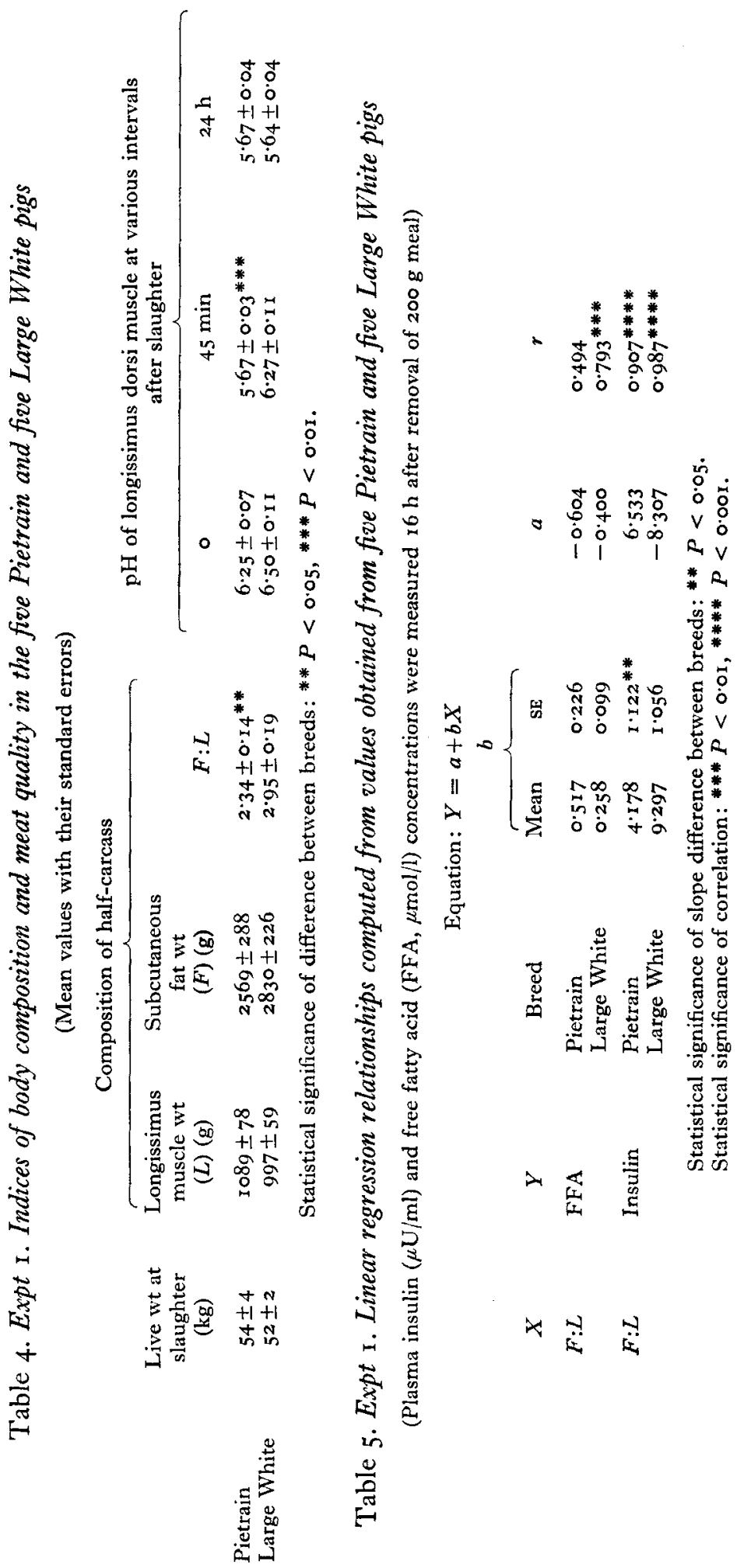



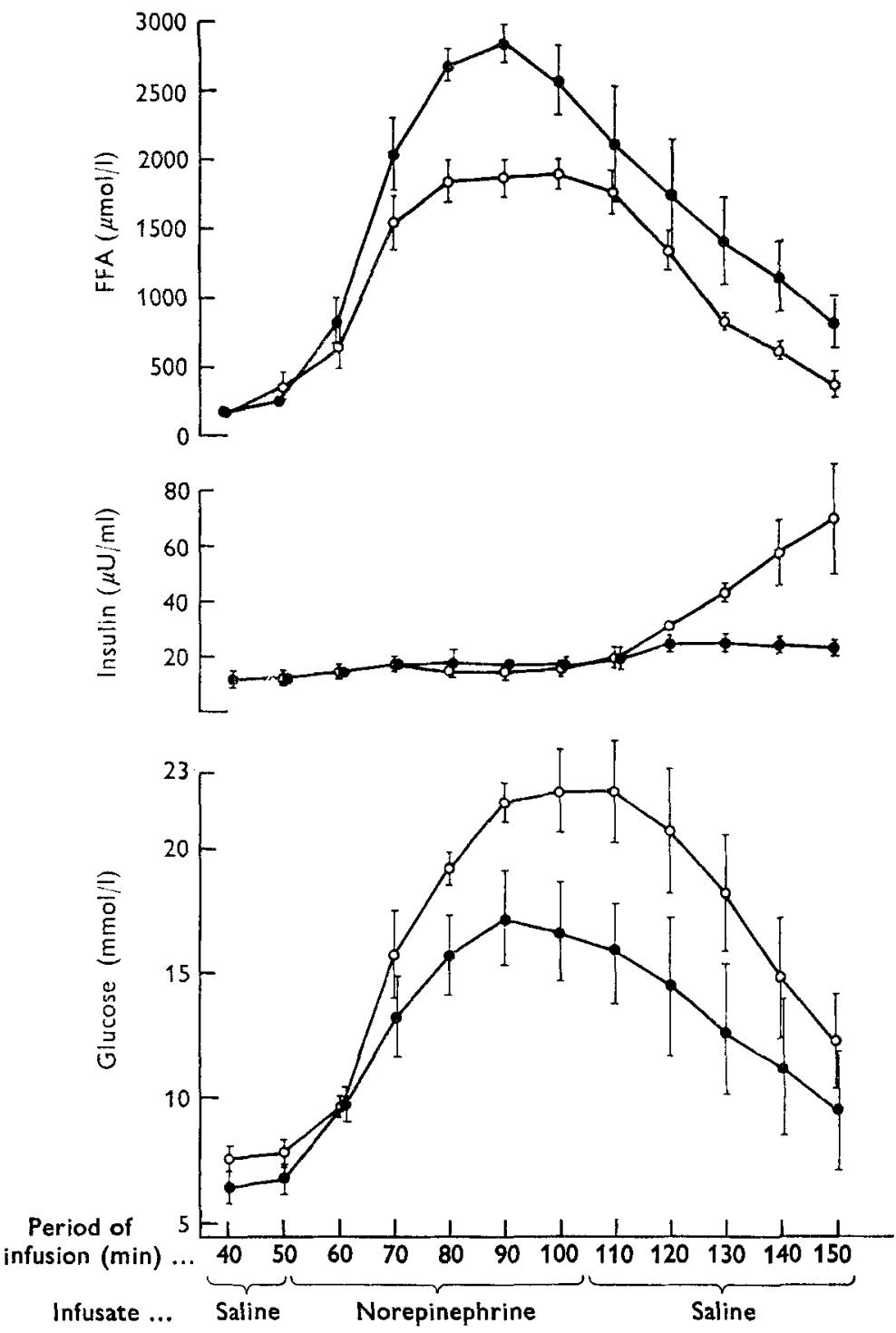

Fig. 2. Expt 2. Plasma concentrations of glucose, free fatty acids (FFA) and insulin during infusions $(0.2 \mathrm{ml} / \mathrm{min})$ of norepinephrine $(2.5 \mu \mathrm{g} / \mathrm{kg}$ body-wt per min) and saline ( $9 \mathrm{~g}$ sodium chloride/l) in anaesthetized pigs. Points are mean values with their standard errors for three Pietrain (O) and four Large White (O) pigs. For details of experimental procedures, see p. I69.

that time. However, when the measurements made after the overnight fast were used the results shown in Table 5 were obtained. These results were rather variable, as has been found previously in this type of study (e.g. Siers \& Trenkle, 1973) but they do show several trends. First, high values for subcutaneous fat weight: longissimus muscle weight were associated with high plasma FFA concentrations although the correlation was significant only in the Large Whites. The value for the rate of increase of FFA concentrations per unit increase in fat:muscle weight was greater, but again not 


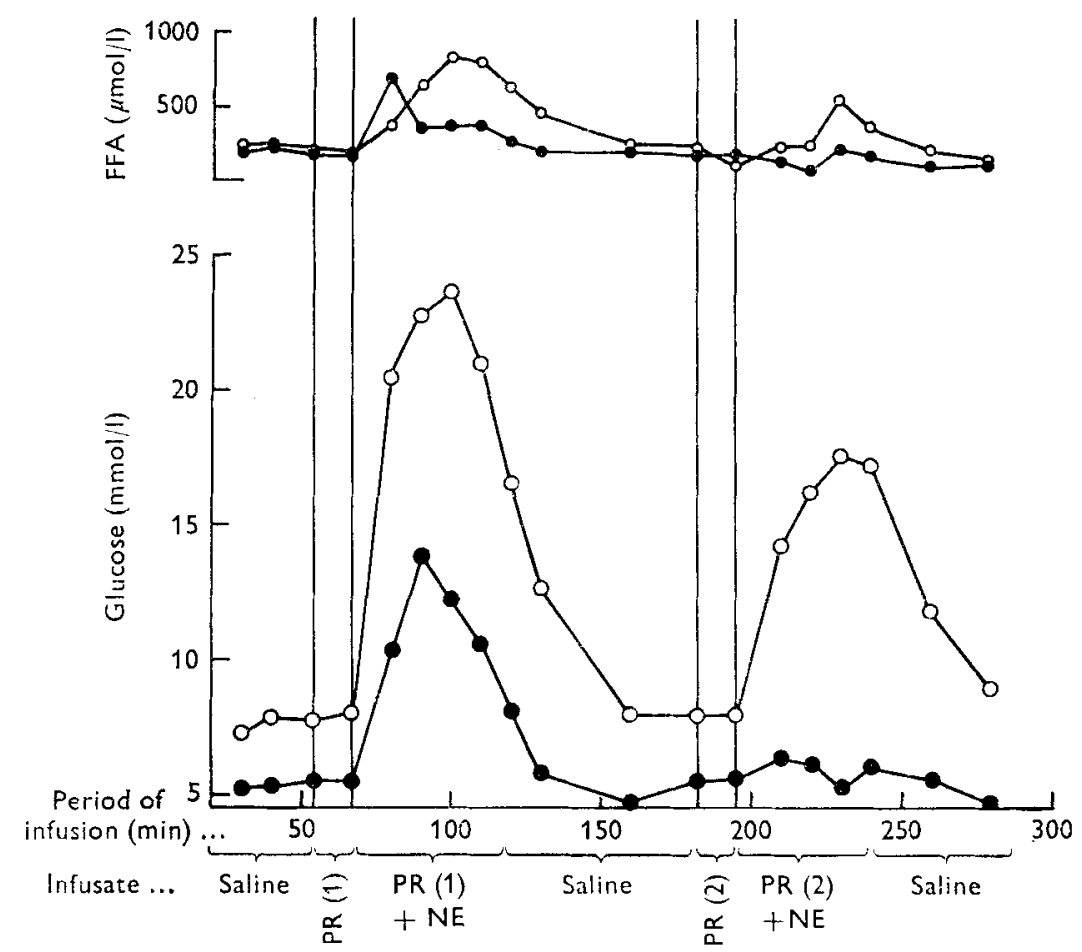

Fig. 3. Expt 2. Plasma concentrations of glucose and free fatty acids (FFA) during infusions $(0.2 \mathrm{ml} / \mathrm{min}$ ) of norepinephrine (NE; $2.5 \mu \mathrm{g} / \mathrm{kg}$ body-wt per min) + propranolol (PR $(\mathrm{r}), 2 \mu \mathrm{g} / \mathrm{kg}$ body-wt per $\min$; PR(2), $20 \mu \mathrm{g} / \mathrm{kg}$ body-wt per $\mathrm{min}$ ) and saline (9 g sodium chloride/1) in anaesthetized pigs. Points are values for one Pietrain $(\bullet)$ and one Large White $(O)$ pig. For details of experimental procedures, see p. 160 .

significantly so, in the Pietrains. Secondly, high plasma insulin concentrations were associated with high values for fat weight: muscle weight in each breed. This suggests that the gradual increases in insulin concentrations that have been observed in animals as they approach slaughter weight (e.g. Trenkle, 1970) are associated in part with the greater deposition of fat relative to muscle tissue that occurs at that time. In this instance the rate of increase of insulin concentrations per unit increase in fat:muscle weight was greater in the Large Whites than in the Pietrains.

\section{Expt 2}

The concentrations of glucose, FFA and insulin obtained for the anaesthetized pigs during the norepinephrine infusion are shown in Fig. 2. The concentrations differed markedly between the breeds, in contrast to the situation in Expt I (Table 3). At the termination of the infusion, FFA concentrations were higher in Pietrains $(P<0.05)$ and glucose concentrations were higher in Large Whites $(P<0.05)$. The major difference between these results and those of Expt I was that whereas the Pietrains responded similarly in both experiments, the Large Whites were less sensitive to the fat-mobilizing action and more sensitive to the hyperglycaemic action of norepinephrine in this experiment. In addition, although there was no evidence of a reduction in 


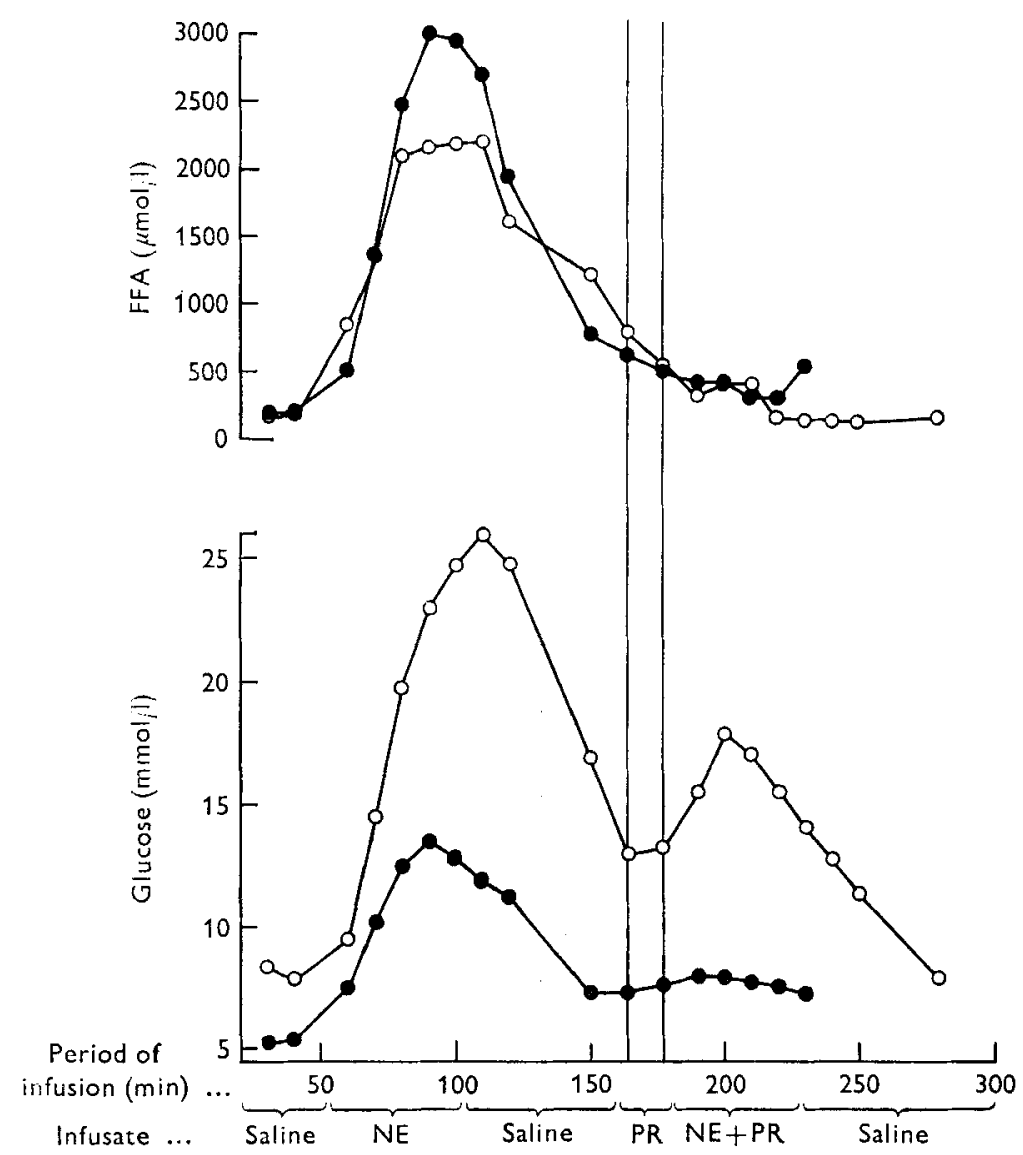

Fig. 4. Expt 2. Plasma concentrations of glucose and free fatty acids (FFA) during infusions ( $0.2 \mathrm{ml} / \mathrm{min}$ ) of norepinephrine (NE; $2.5 \mu \mathrm{g} / \mathrm{kg}$ body-wt per $\mathrm{min}$ ), NE + propranolol (PR; Io $\mu \mathrm{g} / \mathrm{kg}$ body-wt per min) and saline ( $9 \mathrm{~g}$ sodium chloride/l) in anaesthetized pigs. Points are values for one Pietrain (O) and one Large White $(O)$ pig. For details of experimental procedures, see p. I69.

plasma insulin during the catecholamine infusion, probably because concentrations were already low (compared with Expt r), insulin concentrations increased much more markedly after the termination of the infusion in Large Whites, possibly as a result of the greater hyperglycaemia in these pigs.

The effect of two different rates of propranolol infusion on the responses of a pair of pigs to norepinephrine is shown in Fig. 3. Fat mobilization was markedly reduced in both animals, demonstrating the existence of $\beta$-adrenergic receptors in pig fat cells which normally mediate catecholamine-induced fat mobilization. The inhibition was greater in the Pietrain than in the Large White pig. The hyperglycaemic response to norepinephrine in the presence of the lower rate of propranolol infusion $(2 \mu \mathrm{g} / \mathrm{kg}$ body-weight per min) was greater in the Large White and was not reduced in either pig compared with the unblocked animals (Fig. 2). The higher level of blockade $(20 \mu \mathrm{g} / \mathrm{kg}$ body-weight per min) appeared to inhibit the hyperglycaemic response although the extent of inhibition may have been over-estimated. This conclusion is based on findings 


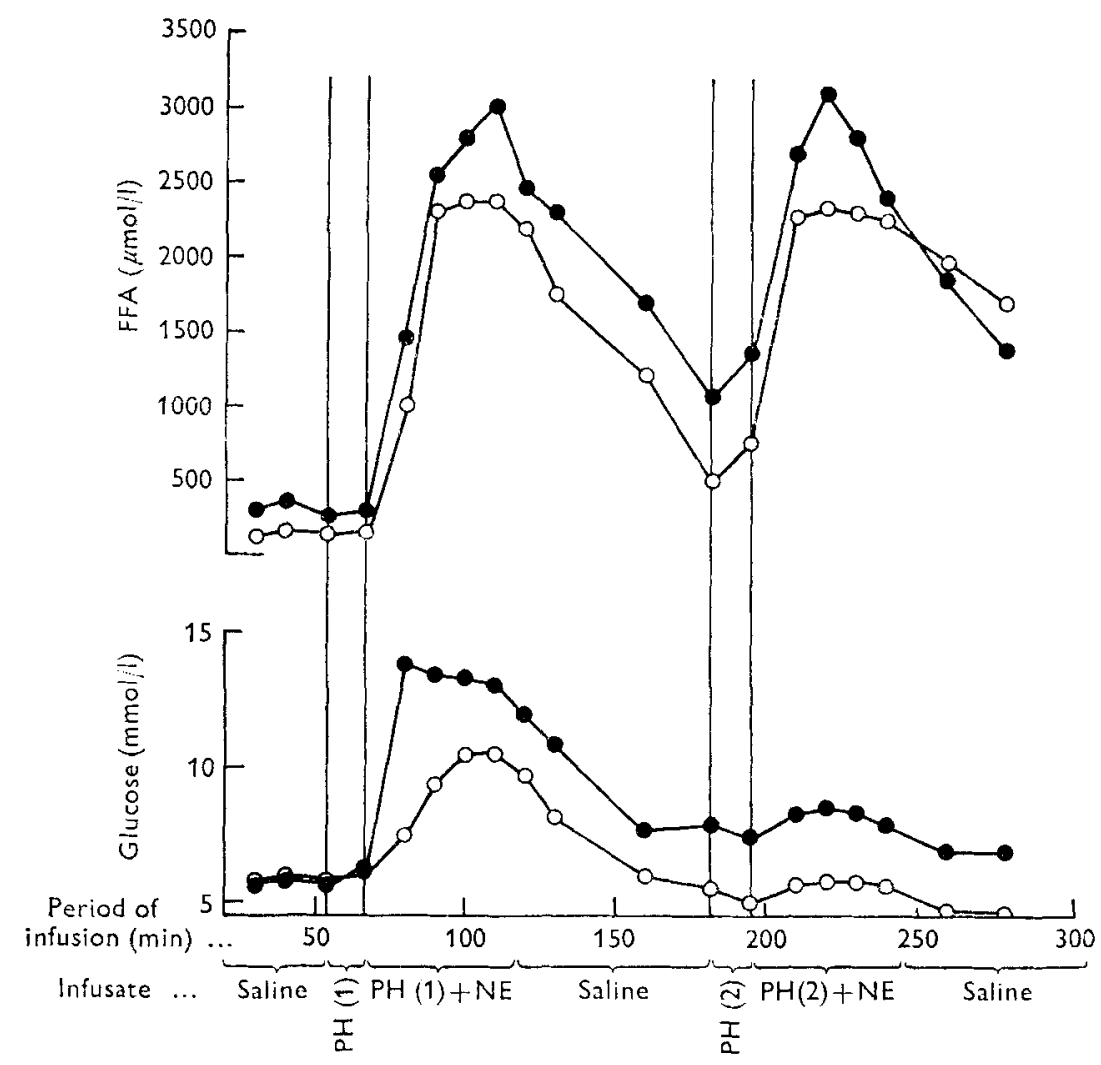

Fig. 5. Expt 2. Plasma concentrations of glucose and free fatty acids (FFA) during infusions $(0.2 \mathrm{ml} / \mathrm{min})$ of norepinephrine (NE; $2.5 \mu \mathrm{g} / \mathrm{kg}$ body-wt per min) + phentolamine (PH( $\mathrm{I})$, $2 \mu \mathrm{g} / \mathrm{kg}$ body-wt per $\min ; \mathrm{PH}(2)$, $10 \mu \mathrm{g} / \mathrm{kg}$ body-wt per $\mathrm{min}$ ) and saline ( $9 \mathrm{~g}$ sodium chloride/l) in anaesthetized pigs. Points are values for one Pietrain (๑) and one Large White (○) pig. For details of experimental procedures, see p. I69.

with three Large White pigs (not included in the present study) infused with norepinephrine alone in two 50 min infusions separated by a $60 \mathrm{~min}$ infusion of saline. The percentage increase in plasma glucose concentrations, from the pre-infusion value to the peak value reached, was $170 \%$ in the first norepinephrine infusion and $30 \%$ in the second norepinephrine infusion. This is probably because of depletion of liver glycogen during the first infusion (Ziemba, Kozłowski, Nazar, Brzezińska \& KaciubaUścilko, 1975). Nevertheless the extent of hyperglycaemia in the second norepinephrine infusion shown in Fig. 3 was greater in the Pietrain than in the Large White pig.

Fig. 4 shows the effect of norepinephrine alone and norepinephrine + an intermediate level of $\beta$-blockade (Io $\mu \mathrm{g}$ propranolol $/ \mathrm{kg}$ body-weight per min) on FFA and glucose concentrations. Glucose concentrations were greater in the Large White pig during the norepinephrine infusion and FFA concentrations were greater in the Pietrain. FFA concentrations in both animals were reduced when propranolol was infused. Glucose concentrations were reduced, particularly in the Pietrain (although again the extent of inhibition was probably over-estimated). At $230 \mathrm{~min}$ after the beginning of this experiment the rectal temperature of the Pietrain pig quickly increased from 


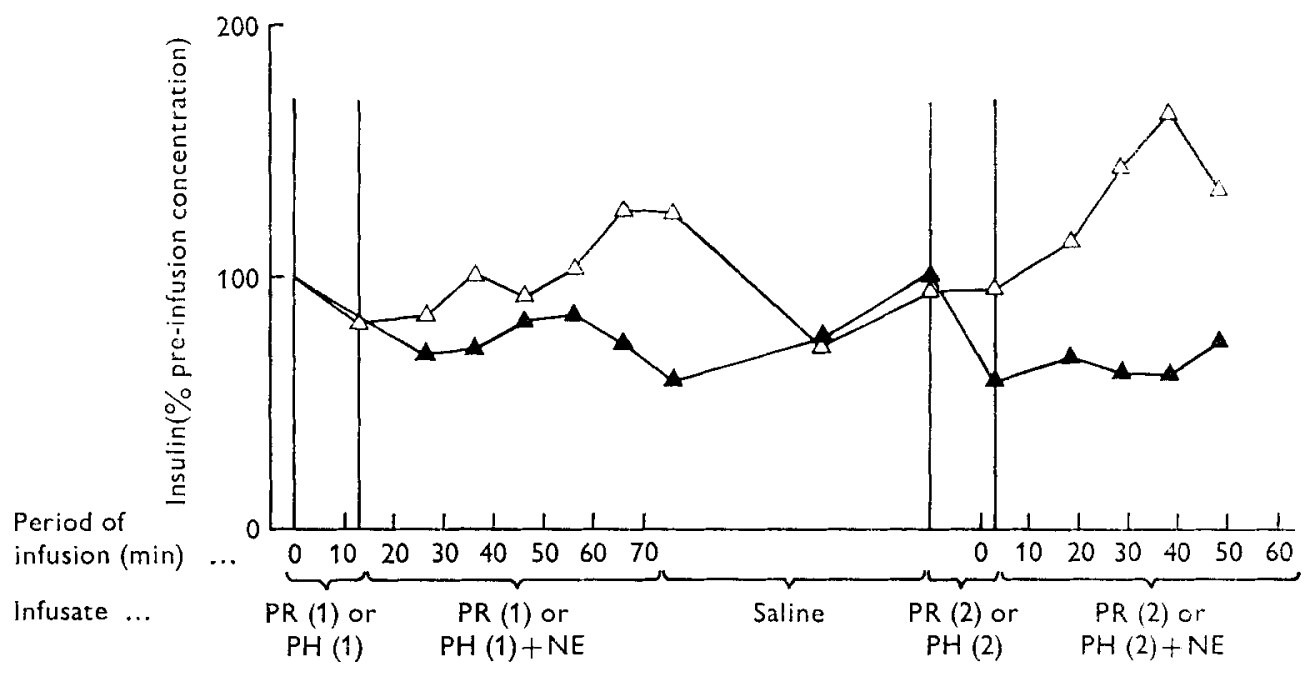

Fig. 6. Expt 2. Plasma insulin concentrations during infusions $(0.2 \mathrm{ml} / \mathrm{min})$ of norepinephrine (NE; $2.5 \mu \mathrm{g} / \mathrm{kg}$ body-wt per min) +propranolol (PR(1), $2 \mu \mathrm{g} / \mathrm{kg}$ body-wt per min; PR(2), $20 \mu \mathrm{g} / \mathrm{kg}$ body-wt per $\mathrm{min}$ ) ( $\Delta$ ) or phentolamine (PH(I), $2 \mu \mathrm{g} / \mathrm{kg}$ body-wt per min; $\mathrm{PH}(2)$, ro $\mu \mathrm{g} / \mathrm{kg}$ body-wt per $\mathrm{min})(\triangle)$ in anaesthetized pigs. Points are mean values for three Pietrain (๑) and three Large White $(\bigcirc)$ pigs. For details of experimental procedures, see p. 169.

39 to $4 \mathrm{r}^{\circ}$ and the pig died. This intense heat production has been observed before in these stress-sensitive pigs and it has been suggested that $\alpha$-stimulation of skeletal muscle is a possible cause (Lister, Hall \& Lucke, 1975).

The effect of two levels of $\alpha$-blockade is shown in Fig. 5. There was no effect of phentolamine on the fat-mobilizing action of norepinephrine in either pig. These results (Figs. 3, 4, 5) therefore show that pig fat cells are similar to those in rats, dogs, guinea-pigs and hamsters in that they contain $\beta$-but not $\alpha$-adrenergic receptors. The role of $\alpha$-adrenergic receptors in some species, e.g. man, is to inhibit catecholamineinduced fat mobilization (Burns, Mohs, Langley, Yawn \& Chase, 1974).

Phentolamine did not have a marked effect on plasma glucose concentrations in the Pietrain pig. However, glucose concentrations in the Large White were much reduced in comparison with the other animals studied (Figs. 2, 3, 4). It seems that norepinephrine stimulates hyperglycaemia in pigs (at least in Large Whites) via $\alpha$-receptors in the liver as it does in fed rats (Fleming \& Kenny, 1964).

In the experiments in which infusions of blocking drugs were given there were no consistent differences in insulin concentrations between the breeds and in general these were variable. Therefore for clarity, and to illustrate the role of $\alpha$ - and $\beta$ adrenergic effects on plasma insulin concentrations, the results for both breeds have been pooled in Fig. 6. This shows the effect of propranolol and phentolamine on plasma insulin concentrations in relation to the pre-infusion concentration. There was evidence that insulin secretion in pigs is stimulated via $\beta$-receptors and inhibited via $\alpha$-receptors in the pancreas as it is in other mammalian species (Mayhew, Wright $\&$ Ashmore, 1969; Robertson \& Porte, 1973). 

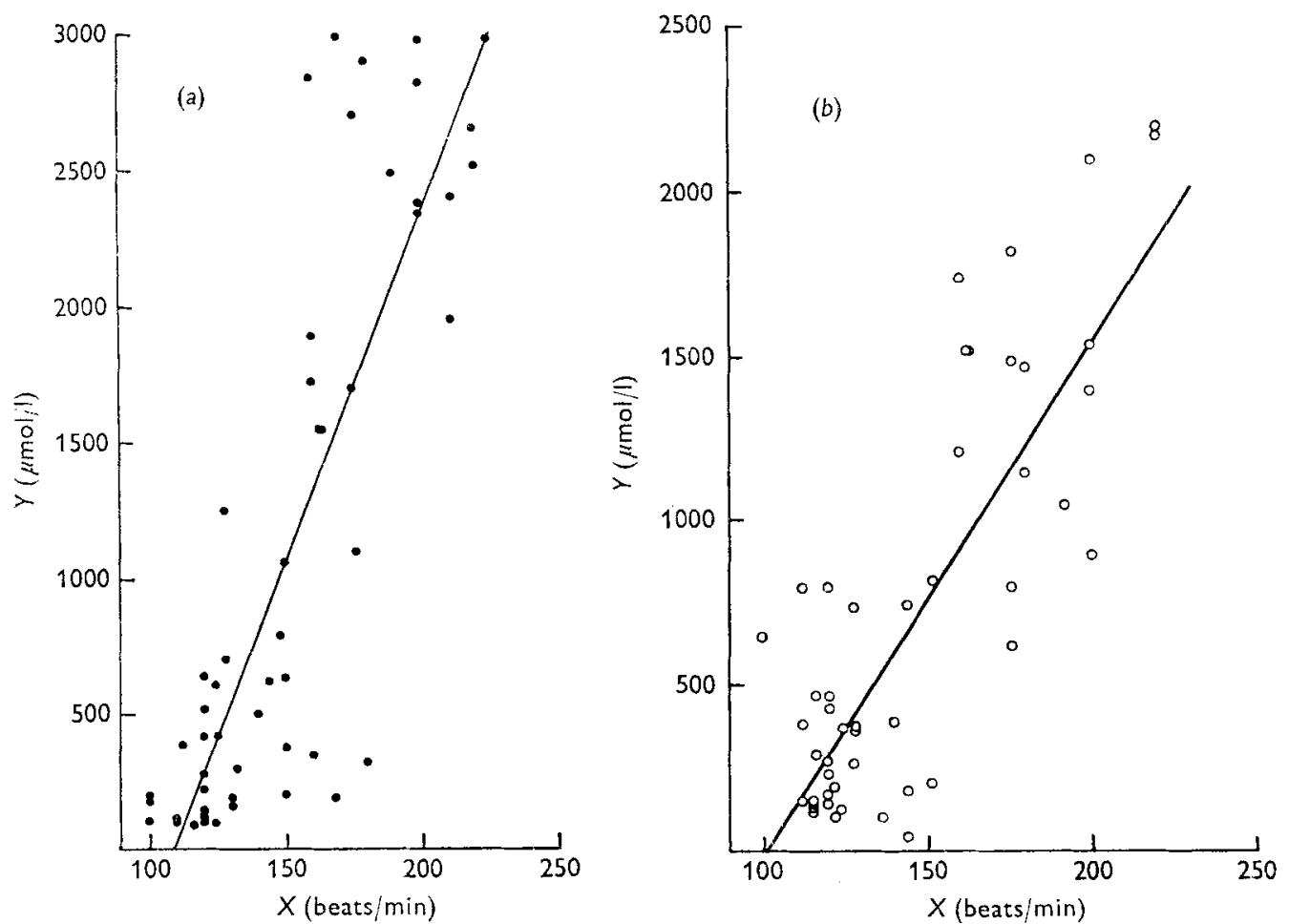

Fig. 7. Expt 2. Relationship between heart rate $(X)$ (beats $/ \mathrm{min}$ ) and plasma concentration of free fatty acids $(Y)(\mu \mathrm{mol} / \mathrm{l})$ during infusions $(0.2 \mathrm{ml} / \mathrm{min})$ of norepinephrine $(\mathrm{NE} ; 2.5 \mu \mathrm{g} / \mathrm{kg}$ body-wt per $\mathrm{min}$ ) and $\mathrm{NE}+$ propranolol $(2$, ro and $20 \mu \mathrm{g} / \mathrm{kg}$ body-wt per $\mathrm{min}$ ) in anaesthetized pigs. (a) Pietrain pigs, linear regression equation: $Y=-2780.1+(25.6 \pm 2.7) X ; r \quad 0.81$, $P<0.01$; (b) Large White pigs, linear regression equation: $Y=-156^{\circ} 9+(15.5 \pm 1 \cdot 6) X$; $r 0.8 \mathrm{r}, P<0.01$.

Of the many pharmacological responses to norepinephrine other than those already considered, heart rate was also measured in the present study. It is thought that the catecholamine activation of both fat mobilization and heart rate is mediated via $\beta$-adrenergic receptors (Fain, 1973) and the results in Fig. 7 confirm this for the pig. The values include all the observations made on the pigs treated with norepinephrine alone and norepinephrine + propranolol, and show that in both breeds there was a strong positive correlation between heart rate and plasma FFA concentrations. Of particular interest was the finding that the mean heart rate in both breeds over all the treatments was very similar ( $146 \pm 5$ and $145 \pm 5$ beats/min for Pietrains and Large Whites respectively). However, the regression coefficients were significantly different $(P<0.05)$ showing that plasma FFA concentrations at a particular heart rate were higher in Pietrains. Therefore the greater sensitivity of $\beta$-adrenergic receptors observed in the fat cells of the Pietrains in this study does not necessarily reflect a generally increased $\beta$-adrenergic sensitivity in these pigs. 
DISCUSSION

The studies extend other work showing that fat and carbohydrate metabolism in pigs is affected in a similar way to that in other animal species by feeding, starvation, insulin administration and catecholamine stimulation (Hertelendy $e t$ al. 1966; Machlin, Horino, Hertelendy \& Kipnis, 1966; Riis \& Grummer, 1969; Freeman et al. 1970 ). In addition, evidence is provided that: (I) insulin is important in controlling body development and in regulating fat mobilization; (2) the in vivo response of the pig to infused norepinephrine depends on the activity of $\beta$-adrenergic receptors in fat cells which promote fat mobilization and $\alpha$-adrenergic receptors, probably in the liver, which promote hyperglycaemia. However, the different responses of the Pietrain and Large White pigs to similar experimental treatments underlines the importance of a consideration of the genotype of the experimental animals when studies such as these are made. Freeman \& Manning (1975) reached a similar conclusion when they observed different responses to exogenous adrenocorticotrophic hormone in two chicken breeds.

Considered together, the results of Expt I suggested that fat mobilization was enhanced in the Pietrains. After feeding and during fasting (presumably these are the normal states for the pig) glucose and insulin concentrations were generally lower in these pigs and FFA concentrations were higher. The entry rate of FFA was also higher in the Pietrains after feeding and the fatty acid composition of their FFA was closer to that characteristic of the stimulated states. In addition, Pietrains were less sensitive to the antilipolytic action of insulin and insulin secretion was not stimulated after the norepinephrine infusion. The correlations examined also showed that FFA concentrations increased faster, and insulin concentrations more slowly in relation to increasing fat:muscle weight in the Pietrains. This seems good evidence that the breed difference in fat mobilization was associated with differences in insulin metabolism and that these effects were independent of differences in the relative development of muscle and fat tissue. The results suggest a pattern of fat metabolism in Pietrains that would tend to reduce carcass fat deposition, particularly as their appetite for food is normally less than that of Large Whites, providing less substrate for fat synthesis.

In most of the comparisons in Expt I the plasma concentration of FFA relative to that of glucose was higher in Pietrains. However, this situation did not persist when the pigs were treated with norepinephrine. There was no evidence of an increased sensitivity of the fat mass of the leaner animals to the fat-mobilizing hormone such as has been observed in in vitro studies using lean Norwegian Landrace pigs (Standal et al. 1973) (and which may partly be due to a larger number of fat cells per unit weight of adipose tissue under study (Mersmann, Phinney \& Brown, 1975)). On the other hand, neither was there good evidence of a reduced sensitivity to the catecholamine in these stress-sensitive pigs such as has been observed in animals adapted to a chronic stressor (Sapira, Lipman \& Shapiro, I965), and which might have been expected if the animals had experienced frequent high levels of plasma norepinephrine in their early life. However, it was obvious from the excitable behaviour of the pigs during the infusion that the catecholamine elicited conscious responses which possibly complicated any 
potential difference in sensitivity between the breeds. Therefore it was felt important to study the effects of norepinephrine in unconscious pigs.

When this was done in Expt 2 by anaesthetizing the pigs, the Pietrains and Large Whites responded quite differently. When norepinephrine alone was infused the four Pietrains developed higher concentrations of FFA and lower concentrations of glucose than the five Large Whites (Figs. 2, 4). The most marked difference between the results in Expts $I$ and 2 was that the extent of hyperglycaemia which developed in the anaesthetized Large Whites was much greater than in the conscious animals (the peak plasma concentrations of glucose $(\mathrm{mmol} / \mathrm{l}) \pm \mathrm{SE}$ were: $22 \cdot 3 \pm \mathrm{I} \cdot 7$ and $\mathrm{I} 6 \cdot 3 \pm \mathrm{I} \cdot 9$ in the unconscious and conscious states respectively).

Although the high levels of plasma glucose which developed in the anaesthetized Large Whites may have partly reduced fat mobilization by encouraging re-esterification of fatty acids (Himms-Hagen, 1967), it is probable that this was not a major factor since the Large White pig infused with phentolamine + norepinephrine (Fig. 5) also demonstrated a smaller lipolytic response than the Pietrain, despite a much lower peak concentration of plasma glucose $(10.5 \mathrm{mmol} / \mathrm{l})$ than in the unblocked animals. It is also unlikely that increases in plasma lactic acid caused the lower fat mobilization in the Large Whites because: ( $\mathrm{r}$ ) norepinephrine mobilizes liver, not muscle, glycogen in non-fasted animals, whereas the increased concentrations of plasma lactic acid which result from catecholamine activity are generally considered to derive from muscle (Fleming \& Kenny, 1964; Himms-Hagen, 1967); (2) infused norepinephrine did not cause increases in plasma lactic acid in another experiment with pigs (Baetz, Witzel \& Graham, I973). The similarity between the breeds in plasma insulin concentrations before and during the norepinephrine infusion also suggests that differences in insulin metabolism were not entirely responsible for the different rates of increase of glucose and FFA concentrations between the breeds. However, the marked increase in plasma insulin which occurred at the termination of the infusion in the Large Whites was probably important in allowing the more rapid decrease in glucose and slower decrease in FFA concentrations which occurred in these pigs. Finally, although no cardiovascular measurements other than heart rate were made during the norepinephrine infusions, the similarity in this response between the breeds provides evidence that no obvious differences in blood flow occurred which could have brought about misleading differences in glucose and FFA concentrations.

The pigs infused with norepinephrine $+\alpha$ - or $\beta$-blocking agents provide a possible explanation for this apparent breed difference in norepinephrine sensitivity although it must be stressed that these comparisons (Figs. 3-5) involved only one pig from each breed. Thus, the more marked inhibitory effect of propranolol on fat mobilization in the Pietrains might indicate a greater sensitivity to the ' $\beta$-stimulating' effects of norepinephrine on fat stores in these pigs. Similarly, the Large White pig was particularly sensitive to the inhibitory effect of phentolamine on glycogenolysis which suggests enhanced sensitivity to the ' $\alpha$-stimulating' effects of norepinephrine in these animals.

In conclusion, although a relatively small number of animals was involved in this study, it seems that there may well be physiological reasons, other than the possession of a small appetite, why stress-sensitive, PSE-susceptible Pietrain pigs tend to be 
leaner than Large Whites. They mobilize more fat than Large Whites, an effect which may be associated with an impairment in insulin metabolism and perhaps also with a greater sensitivity, at least under some conditions, to the $\beta$-adrenergic action of catecholamines on body fat stores. Norepinephrine may be particularly significant in view of the central role of the sympathetic nervous system in counteracting stress.

The authors thank Mr P. E. Whittington and Mr R. D. Lovell for excellent technical assistance, Mr E. J. Goodland for doing the dissections in Expt I, Mr J. N. Lucke for giving valuable anaesthetic and surgical assistance in Expt 2, and Mr J. Anderson for taking good care of the experimental pigs. N.G. G. held a postgraduate scholarship from the Meat and Livestock Commission. Mr G. M. Hall is a visiting worker from the Royal Postgraduate Medical School, Hammersmith Hospital, London Wi2.

\section{REFERENCES}

Baetz, A. L., Witzel, D. A. \& Graham, C. K. (1973). Am. F. vet. Res. 34, 497.

Bakke, H. (1975). Acta Agric. scand. 25, 113.

Bendall, J. R. \& Lawrie, R. A. (I964). Anim. Breed. Abstr. 32, I.

Bogdonoff, M. D. \& Estes, E. H. (I 96r). Psychosom. Med. 23, 23.

Bonnet, F., Gosselin, L., Chantraine, J. \& Senterre, J. (1970). Archs int. Physiol. Biochim. 78, 495. Borgstrom, B. (1 952). Acta physiol. scand. 25, I I I.

Bray, R. W. (1 968). In The Pork Industry: Problems and Progress, p. 136 [D. G. Topel, editor]. Ames, Iowa: Iowa State University Press.

Burns, T. W., Mohs, J. M., Langley, P. E., Yawn, R. \& Chase, R. G. (I974). F. clin. Invest. 53, 338.

Cerceo, E. (1 974). Lab. Pract. 23, 625.

Cunningham, H. M. \& Friend, D. W. (r965). F. Anim. Sci. 24, 4I.

Dole, V. P. \& Meinertz, H. (I960). F. biol. Chem. 235, 2595.

Duncombe, W. G. (1963). Biochem, F. 88, 7.

Fain, J. N. (1973). Pharmac. Rev. 25, 67.

Fleming, W. W. \& Kenny, A. D. (1964). Br. F. Pharmac. Chemother. 22, 267.

Freeman, B. M. \& Manning, A. C. C. (1975). Br. Poult. Sci. 16, 121.

Freeman, C. P., Noakes, D. E. \& Annison, E. F. (1970). Br. F. Nutr. 24, 705.

Hertelendy, F., Machlin, L. J., Gordon, R. S., Horino, M. \& Kipnis, D. M. (1966). Proc. Soc. exp. Biol. Med. 121, 675 .

Himms-Hagen, J. ( I 967$)$. Pharmac Rev. 19, 367.

Ho, R. J. (1970). Analyt. Biochem. 36, 105.

Jensen, P., Craig, H. B. \& Robison, O. W. (1967). F. Anim. Sci. 26, 1252.

Kaplan, A. (1970). Analyt. Biochem. 33, 218.

Laurell, S. (1957). Acta physiol. scand. 41, 158 .

Lean, I. J., Curran, M. K., Duckworth, J. E. \& Holmes, W. (1972). Anim. Prod. 15, I.

Leat, W. M. F. \& Ford, E. J. H. (r966). Biochem. F. ror, 3 r 7.

Lister, D., Hall, G. M. \& Lucke, J. N. (1975). Br. F. Anaesth. 46, 803.

Lister, D. \& Ratcliff, P. W. (197I). Proc. 2nd int. Symp. Condition Meat Quality Pigs, Zeist, p. ז39.

Ludvigsen, J. (1955). Beretn. Forsøgslab. nos. 278, 279, 284.

Machlin, L. J., Horino, M., Hertelendy, F. \& Kipnis, D. M. (r966). Endocrinology 82, 369.

Marple, D. N., Aberle, E. D., Forrest, J. C., Blake, W. H. \& Judge, M. D. (1972). F. Anim. Sci. 35, 576.

Mayhew, D. A., Wright, P. H. \& Ashmore, J. (1969). Pharmac. Rev. 21, I83.

Mersmann, H. J., Brown, L. J., Underwood, M. C. \& Stanton, H. C. (1974). Comp. Biochem. Physiol. $47 \mathrm{~B}, 263$.

Mersmann, H. J., Phinney, G. \& Brown, L. J. (I975). Gen Pharmac. 6, 187.

Riis, P. M. \& Grummer, R. H. (1969). Acta Agric. scand. I9, I I.

Robertson, R. P. \& Porte, D. Jr (1973). Diabetes 22, I.

Sapira, J. D., Lipman, R. \& Shapiro, A. P. (1965). Psychosom. Med. 27, 165.

Siers, D. G. \& Trenkle, A. (1973). F. Anim. Sci. 37, I180.

Standal, N., Vold, E., Trygstad, O. \& Foss, I. (r973). Anim. Prod. 16, 37.

Taggart, P., Carruthers, M. \& Somerville, W. (I973). Lancet ii, $34 \mathrm{x}$. 
I 86 J. D. Wood, N. G. Gregory, G. M. Hall and D. Lister 1977

Trenkle, A. (1970). F. Anim. Sci. 31, 389 .

Trout, D. L., Estes, E. H. Jr \& Friedberg, S. J. (1960). F. Lipid Res. I, 199.

Wood, J. D. (1973). Anim. Prod. 17, 281.

Wood, J. D. (1974). Proc. Nutr. Soc. 33, 6rA.

Wood, J. D. \& Lister, D. (1973). F. Sci. Fd Agric. 24, 4449.

Ziemba, A. W., Kozłowski, S., Nazar, K., Brzezińska, Z. \& Kaciuba-Uściłko, H. (1975). Experientia 3r, 193. 